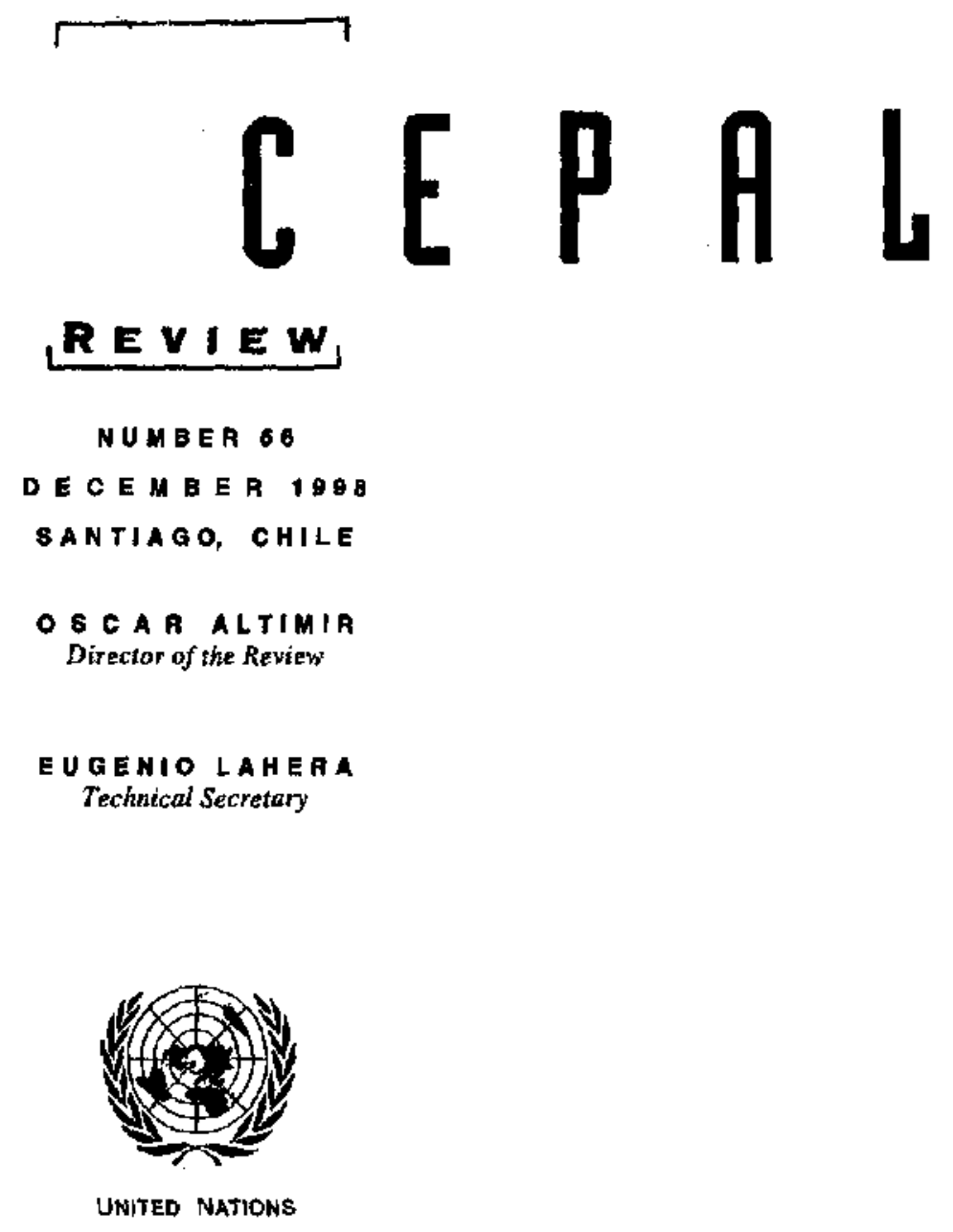


CONTENTS

Beyond the Washington Consensus: an ECLAC perspectlve

José Antonio Ocampo

The Cuban economy

David Ibarra and Jorge Máttar

Education in Latin America: demand and distribution are factors that matter

Nancy Birdsall, Juan Luis Londoño and Lesley O'Connell

Determinants of inequality among urban households

Luis Felipe Jiménez $L$, and Nora Ruedi $A$.

Health management contracts in Costa Alca from a comparative perspective

Ana Sojo

A development strategy tounded on natural resource-based production clusters

Jaseph Ramos

Blg Latin American industrial companies and groups

Celso Garrido and Wilson Peres

Between political control and efflciency gains:

the evolution of agrarian property rights in Mexico

Gustavo Gordillo, Alain de Janvry and Elizabeth Sadoulet

Tariffs and the Plano Real in Brazil

Renaso Baumann, Josefina Rivero and Yohana Zavattiero 


\section{A development strategy founded on natural resource-based production clusters}

\section{Joseph Ramos}

Director,

Division of Production,

Productivity and Management, ECLAC,
This article contends that the rapid development of Latin America and the Caribbean -a region rich in natural resources- will depend on bow fast it learns to industrialize and process its natural resources and to develop the necessary suppliers of inputs, engineering services and equipment for this. Consequently, this will not be a form of development based on the mere extraction of natural resources, as at present, but rather one based on the processing of such resources and the development of the activities that naturally tend to spring up and concentrate around this base (production complexes or clusters). It will therefore be different from the experience of the recently industrialized Asian countries, most of which bave few natural resources, and will resemble instead that of the resource-rich countries which are now highly developed, such as the Scandinavian countries, Canada, Australia and New Zealand. 


\section{I}

\section{Introduction}

For the last ten years, Latin America has been undergoing a strategic turnaround of a magnitude not witnessed since the 1930 s. The region has discarded its previous inward-oriented development strategy, with a domestic market subject to heavy government intervention and a State which played a leading role in the economy, and has adopted instead a development strategy oriented towards external markets, in which the allocation of resources is determined basically by the market and the main agent of development is private enterprise.

Today there is broad consensus that the industrialization strategy based on import substitution had been giving severely diminishing returns at least since the mid-1970s and that the over-active State had exceeded the limits of its capacity for effective action. It is also clear, however, that so far the region has seen the promise, but not the reality, of the results expected from the present strategic turnaround. Thus, although it has been possible to contain inflation, the economic growth rate is a mediocre $3.5 \%$ per year, which is admittedly higher than that of the $1980 \mathrm{~s}$ but much lower than expected and, in particular, well below the $5.5 \%$ achieved between 1950 and 1980 , when the now so generally disparaged import substitution strategy was in force.

Part of the explanation for such mediocre results undoubtedly lies in the fact that the macroeconomic imbalances which had accumulated were on a massive scale; that the design and implementation of macroeconomic policy was often faulty, and, in particular, that structural reforms of this scale take time -perhaps a long time- to bear fruit. The question arises, then: is it sufficient to have an open, deregulated economy and leave it on "automatic pilot" in order to grow at the desired rapid rate, or is it necessary to modify the strategy so as to secure deeper international linkages for the region? More specifically, where are the next export impulses to come from in order to permit the economic growth of the region to reach rapid rates, higher than those of the past and more similar to those of the recently industrialized Southeast Asian nzations?

This article postulates that the rapid development of Latin America and the Caribbean, a region rich in natural resources, will depend on the speed at which it learns to process its natural resources industrially and develop the necessary activities to provide inputs and equipment for this. It will thus be a type of development which is not based so much on the extraction of natural resources, as it is now, but rather on the use of those resources and the activities which naturally tend to grow up and develop around them (production complexes or clusters). It will therefore be different from the experience of the recently industrialized Asian countries, which have relatively few natural resources, and will be more similar to that of the countries which are now developed and are also rich in natural resources, such as the Scandinavian countries, Canada, Australia and New Zealand.

This theory runs counter to the arguments not only of the many writers who have blamed natural resources for being the cause of the "Dutch disease" (a short-term phenomenon associated with a sudden boom in a particular export product), but also of the more pessimistic analysts who even talk about the "curse" of natural resources (for example, Auty, 1994). Many of these writers note that in practice, paradoxical though it may seem, countries with a rich endowment of natural resources have tended to register lower growth rates than countries which have few natural resources. Thus, Sachs has estimated that per capita growth is reduced by $1 / 2 \%$ per year for every ten percentage points of participation of primary commodity exports in GDP (Asian Development Bank, 1997). He does acknowledge, however, that this is an empirical rather than an analytical relation: it is not inevitable but simply has turned out this way in practice. It would appear that many of the countries with a rich endowment of natural resources have tended to waste the income derived from those resources in boom periods, rather than investing it in improvements in productivity that would make it possible to grow even in times of adversity. This incapacity to turn pure rents into rents based on advances in productivity lies at the root of these meagre results. This is not inevitable, however, for there are natural resource-rich countries which are now highly developed because they have successfully transformed the rents from their natural resources into rents based on

A DEVELOPMENT \$TRATEgY FOUNDED ON NATUAAL RESOURCE-gASED PRODUCTION CLUSTERS • JosEPH RAMOS 
higher productivity (for example, more than $60 \%$ of the exports of Norway, Australia and New Zealand still consist of primary commodities). Thus, the good or bad performance of natural resource-rich countries depends on the suitability of their economic policy, and not the mere fact of having natural resources.

Finally, it may be noted that there are many countries which are following the example of Japan, South Korea and Taiwan: that is to say, exporting manufactures by beginning with those which are most labour-intensive and subsequently moving on to manufactures with greater added value. Because of their shortage of natural resources, however, these countries never had the option of promoting production clusters around those resources, and for the same reason China and India will have no option but to base their exports on light manufactures. There are therefore grounds for thinking that the markets may become saturated with manufactures which do not make intensive use of natural resources -especially those which do not involve very complex technology- as indeed is already occurring to some extent with the production of motor vehicles and electronic goods in Southeast Asia. In contrast, the production of manufactures located upstream or downstream of the natural resources base is being neglected. This is a further reason for believing that a strategy promoting production clusters based on these resources may be very valuable for those Latin America and Caribbean countries which have an abundant endowment of natural resources.

Thus, natural resources are by no means a curse, but they do not of themselves ensure development either. What they do is to offer an opportunity of which the countries should take advantage.' This is not a gratuitous or a purely theoretical assertion. Indeed, there are some indications that this trend is already taking place. Thus, at least since the strategic turnaround which took place in the region in the mid1980s in the direction of a type of development more oriented towards international markets, there has been greater relative expansion of production activities making intensive use of natural resources -especially mineral, agricultural, forestry and fishery resources- while there has been a relative contraction

1 There is extensive literature on the relationship between natural resources and economic development. See, for example, Baldwin (1963), Roemer (1979), Barham, Bunker and O'Heara (1994), Lewis (1989), Sachs and Wamer (1995) and Londero and Teitel (1996). in manufacturing. At the same time, within the manufacturing sector the branches which make most use of natural resources are those which have registered the greatest growth (especially industrial commodities such as paper and pulp, petrochemical products, iron and steel, aluminium and non-ferrous metals). As a result, production making intensive use of natural resources increased from $60 \%$ to $65 \%$ of total production of tradeable goods between 1980 and 1997.

This restructuring reflects a return to the use of a natural comparative advantage of a region which is abundantly endowed with natural resources. The result is that production activities making intensive use of such resources have not only displayed solid increases in production but aiso impressive improvements in productivity. Thus, since the late $1970 \mathrm{~s}$, and even more vigorously since the mid-1980s, a new generation of production plants have been established for these activities, with a high degree of modernization, a greater capital coefficient, and vigorous updating of technology. These production plants use continuous production processes whose rate depends on the equipment itself; consequently, the levels of productivity are much closer to those of the international technological frontier.

Although the relative abundance of natural resources in the region, together with their greater availability and quality, has encouraged the activities making intensive use of them, the expansion has tended to be limited to the initial phases of processing: no significant progress bas yet been made towards the production of specialized and more sophisticated goods with high national added value (such as fine papers, hydrogenated or low-cholesterol oils, special steels, aluminium sections, copper alloys, etc.). Consequently, what is needed is a development strategy which emphasizes not so much the extraction and relatively simple processing of natural resources, but rather the more rapid development of the many activities which tend to grow up around such resources, without going against the natural market trends, and with an effort to strengthen the links with activities supplying inputs, equipment and engineering services (backward linkages) and the links with activities which process and use natural resources (forward linkages). What is needed is to ensure that the incipient production clusters growing up around the region's abundant natural resource base can develop more quickly into mature clusters like those which exist in the developed countries which are rich in natural resources. 


\section{II}

\section{Theory: why do production clusters arise?}

"Production cluster" normally means a sectoral and/or geographical concentration of enterprises engaged in the same or closely related activities, with substantial and cumulative external economies of agglomeration and specialization (through the presence of producers, suppliers, specialized labour and sector-specific related services) and capable of taking joint action to seek collective efficiency. Among successful examples of production clusters in the developed countries are the industrial districts of Emilia Romagna (Italy) and Baden Wurttemberg (Germany), Silicon Valley and Route 128 (United States), the new computer industry in Ireland, and the electronics industry in Scotland; in the developing countries, examples are the footwear industry at Nuevo Hamburgo (Brazil) and the production of electronic goods and computer programmes at Bangalore (India), simple surgical instruments at Sialkot (Pakistan) and microelectronics equipment at the Hsinchu Science Park (Taiwan). ${ }^{2}$

Various theories have been put forward to try to answer the question posed in the heading of this section: why do production clusters arise? We shall now review a few of them. ${ }^{3}$

\section{The theory of location and economic geography}

The theory of location and economic geography seeks to explain why activities are often concentrated in certain areas and not spread out at random (see North (1955); Krugman (1995) and Borges Méndez (1997)). A very well-known feature of this approach is that it emphasizes the importance of the relative weight of transport costs in the final cost, which would explain why some activities are preferably located near natural resources, others near the markets they supply, while others may be established anywhere. A feature which is not so well-known but is of growing importance is that this approach also emphasizes the interdependence between the raw material

${ }^{2}$ Schmitz and Musyck (1993) and Nadvi and Schmitz (1994) provide a good introduction to the rapidly growing literature on this subject.

${ }^{3}$ The following subsections are based mainly on Stumpo (1996). and the processed product and by-products, which means that it is easier to coordinate their movement in a single location. This is the case, for example, of iron and steel producers, since their high level of interdependence leads to the vertical integration of these production activities. A similar thing occurs when a single activity (for example, stock raising) gives rise to various by-products simultaneously (such as fresh meat, industrial products and fertilizers).

Likewise, processing activities which involve big economies of scale, especially in complex processes such as petrochemicals, will only tend to set up plants in the country of origin of their raw materials if it has a large domestic market or is close to important regional markets. Examples of this are the Canadian and Australian industries processing minerals for the markets of the United States and Asia, respectively.

Finally, critical aspects for the location of activities involving the extraction of natural resources are the clarity, transparency and traditions of the local legislation on property rights and the stability and competitiveness of the tax legislation, for investments with high sunk costs and long lead times need security and transparency in the treatment accorded to them, with little or no risk of retroactive changes.

\section{The theory of backward and forward ilnkages}

Hirschman's theory of backward and forward linkages (1957 and 1977) seeks to show how and when the production of a sector is sufficient to satisfy the minimum threshold or scale needed to make investments attractive in another sector which it supplies (backward linkages) or whose products it processes (forward linkages). Naturally, every activity has linkages with others. These linkages become significant, however, when their existence determines whether an investment is made or not. When one investment makes it profitable to make a second investment, or vice versa, taking decisions in a coordinated manner ensures the profitability of each of the investments.

Backward linkages depend both on demand factors (the derived demand for inputs and factors) and on their relation with technological and production 
factors (optimum size of plant). The development of forward linkages; for its part, depends to a large extent on the technological similarities between the extraction and processing activities. The greater these similarities, the easier the learning process will be and the stronger the forward thrust, while the greater the technological differences between the activities, the more difficult the learning process and the weaker the thrust. There is evidence not only that processed products suffer smaller price variations than primary commodities, but also that over the last 25 years the price of processed products has grown significantly more than that of primary commodities in general, especially metals (Yeats, 1991). This would indicate that the development of forward linkages would not only diversify production but could be extremely profitable too.

\section{The theory of interaction and "industrial districts"}

The theory of interaction seeks to explain the most favourable conditions for learning based on interaction, which, according to this approach, accounts for the success of the "industrial districts" in many areas of Italy and Germany and in some areas in Latin America. ${ }^{4}$ Interaction gives rise to "repetitive plays" which raise confidence and ultimately reduce transaction and coordination costs. Interaction also speeds up the spread of know-how and innovation, which is a social good internalized by the group of enterprises in the district. Thus, intensive interaction in a locality gives rise to technological spillovers, external economies and economies of scale for the enterprises in the district, which could not be internalized if each enterprise interacted with the others over a long distance.

\section{The model of Michael Porter}

The model of Michael Porter (see Porter, 1991) asserts that the diversity and intensity of the functional relations between enterprises explain the formation of a production cluster and its degree of maturity. These relations refer to the four points of the "diamond", that is to say, the relationships of competition between enterprises in the same activity and their relationships with their suppliers, with supporting

\footnotetext{
4 With regard to industrial districts, see for example Bianchi (1992), Bellandi (1996) and Dini (1992).
}

activities, with producers of complementary inputs, and with suppliers of specialized inputs and factors. In Porter's analysis production clusters grow up both around natural resources and around activities based on learning and know-how (such as telecommunications, computation and electronics).

\section{Variants with respect to natural resources}

In addition to the theories set forth above there are variants which refer explicitly to natural resources. Special mention may be made in this respect of the staple theory of economic growth, which referred initially to Canada (Innis, 1954 and 1962; Watkins, 1963; Mackintosh, 1953; Scott, 1964). This theory explains the economic development of Canada on the basis of the impulses provided by the export of its various natural resources -fish, furs and skins, minerals, timber, paper and wheat- and the investments in related activities to which they give rise. These "second level" and "third level" activities include: i) secondary activities to provide the inputs and goods required by the natural resource and its labour force; ii) investment in export infrastructure (railways, electric power, highways, ports, etc.), and iij) other activities, not necessarily linked with the natural resource in question, which may take advantage of the infrastructure already financed by the export activity, paying only its variable costs. Thus, each export boom gives rise to a wave of first, second and third level investments which not only multiply the effect of the initial export impulse but also generate forms of economic activity which are less and less dependent on that impulse. This is why Canada now has a broad and diversified production base, much broader than that which would be given by its natural resources, many of which have already been depleted.

A similar variant (David and Wright, 1997) is based on the little-known fact that in the development of the United States in the latter part of the nineteenth century its explotitation and processing of natural resources was much greater than its actual share in the world reserves of such resources. In the case of the mining sector, this was due, according to these anthors, to the fact that the United States not only had abundant mineral resources but also had suitable in stitutions for exploiting them: mining laws which were very favourable to prospecting; geological studies of 29 of the 33 states which existed in 1860, and 20 universities which were issuing degrees in mining 
engineering as far back as 1875 and which had close links with the production sectors. In contrast, at that time Latin America had almost no university courses in mining engineering or metallurgy, and even England only opened its first school of mines in 1851 . The same authors also note that the significant technological spillover from mining gave rise to feedbacks between prospecting, extraction, processing and technological advances in the sector and was responsible for strong growth in these activities. In the case of prospecting, for example, the search for a particular mineral often led to the discovery of another mineral which was equally valuable. Likewise, the technological advances in the separation of a metal from its ore often served for other metals too. Phenomena like this explain why the weight of extraction and industrial processing of minerals in United States production was three times greater than the country's share of world mineral resources.

\section{A common theoretical substrate}

Whatever their theoretical inspiration, all these explanatory hypotheses on the formation of production clusters share the notion that the competitiveness of each enterprise is strengthened by the competitiveness of the whole set of enterprises and activities making up the cluster to which it belongs. This greater competitiveness derives from substantial ex- ternalities, economies of agglomeration, technological spillovers and innovations arising from the intense and repeated interaction of the enterprises and activities making up the cluster. These enterprises and activities mutually strengthen each other; information flows almost without restrictions, transaction costs are lower, new opportunities are seen more rapidly, and innovations spread more quickly throughout the whole network, while the stiff competition on prices, quality and variety gives rise to new business opportunities, intensifies rivalry between enterprises, and belps to maintain diversity.

Furthermore, once the production cluster has been formed (generally a spontaneous rather than an intentional phenomenon), active and conscious cooperation among its members in pursuit of greater collective efficiency is facilitated (Schmitz, 1997); this strengthens and accumulates the initial externalities, facilitating, for example, collaboration between enterprises to open new markets, create new products, share equipment, or finance labour training programmes. Thus, production clusters are a much richer and more significant concept for economic analysis and policy than the mere question of the sector to which the enterprise belongs. Moreover, if this approach is correct, this would also explain where and when there are tendencies towards the vertical and horizontal integration of an enterprise or economic conglomerate.

\section{III}

\section{What is a mature production cluster established around a natural resource, and how is it formed?}

\section{A meture production cluster}

In order to understand this concept properly, let us examine a mature production cluster such as that which grew up around the forestry industry in Finland (Rouvinen, 1996). This cluster is very complete and deep, since it generates $25 \%$ of Finland's exports (over US\$ 5 billion). It may be noted, by way of comparison, that the large but still incipient forestry cluster in Chile generates rather less than US\$ 2 billion.
If we look at figure 1 , we see that the production cluster grew up around an activity with strong natural comparative advantages. Thus, the Finnish cluster: i) has ample forestry reserves and plantations (400-600 $\mathrm{m}^{3}$ per capita, compared with $25-50 \mathrm{~m}^{3}$ in the rest of the world); ii) the forests are close to the sea, which reduces the otherwise high transport costs; and iii) the forests are close to an important international market (Europe). In the case of Chile, because of the latitude of the country its forests receive much more 
PIGURB I

Finland: The mature forestry cluster *

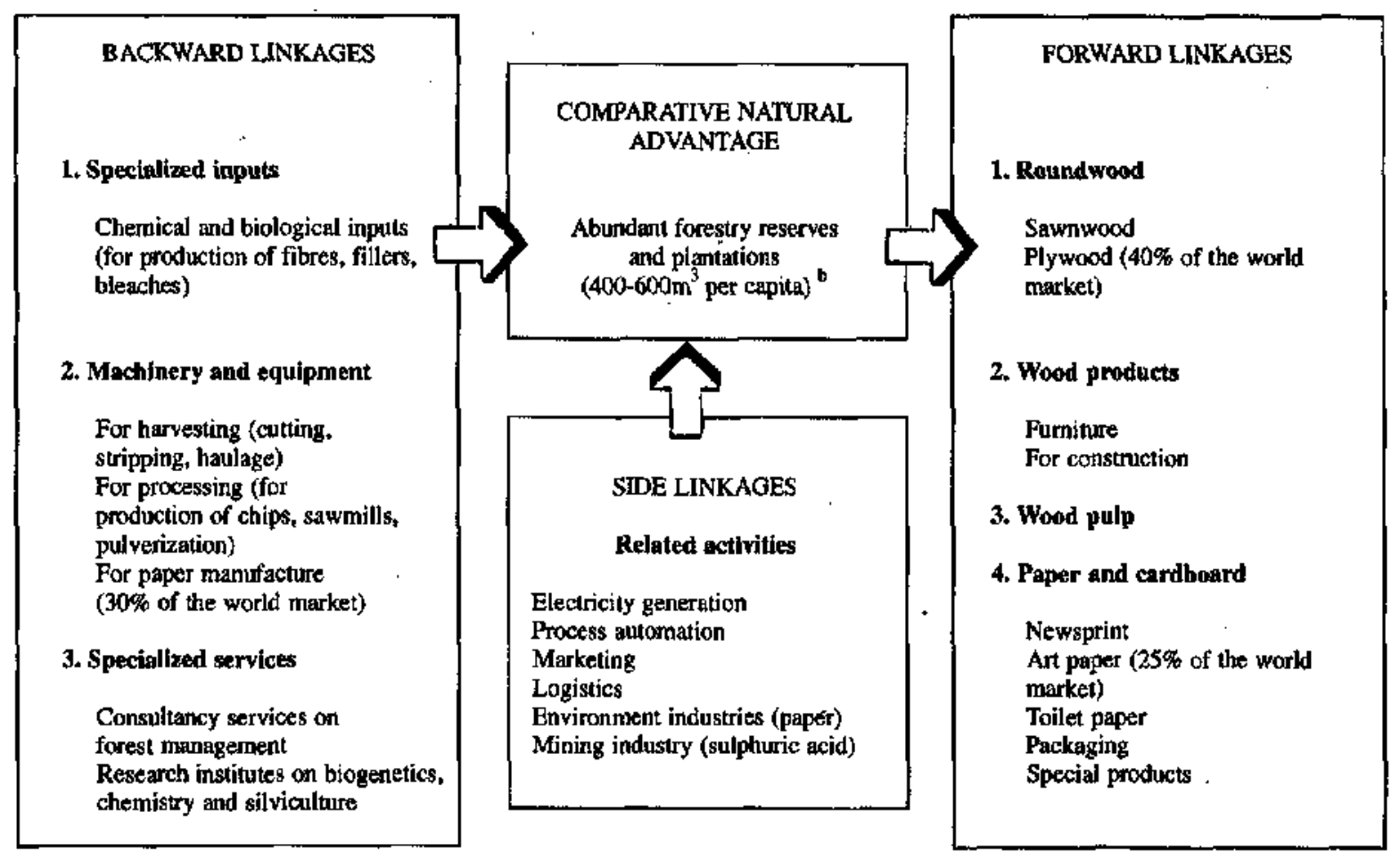

Source: ECLAC, on the basis of official data.

"Generates 25\% of Finland's exports.

${ }^{b}$ Compared with $25-50 \mathrm{~m}^{3}$ per capita in the rest of the world.

sunshine than in Scandinavia, which makes them grow up to twice as fast. Moreover, because Chile is a narrow country, its forests are close to the sea, so that its transport costs are also relatively low.

Finnish forestry activity also has many important linkages with other activities which make up the cluster, thus enabling it to add much value to the extraction phase. There are important forward linkages with extensive possibilities of adding value through more sophisticated procéssed products in four areas: i) sawnwood (Finland has $40 \%$ of the world plywood market); ii) wood products for construction and furmiture; iii) wood pulp, and iv) all types of cardboard and paper for newsprint, packaging, toilet paper and coated paper (Finland has $25 \%$ of the world market for the latter product).

There are backward linkages in at least three important areas: i) inputs for the planting and processing phases, such as chemical and biological products, fillers and bleaches; ii) all kinds of machinery for planting, harvesting, processing and paper manufacture; iii) engineering and consultancy services, and iv) (highly important) specialized university courses on the forestry industry and research institutes in the areas of biogenetics, chemistry and forestry, all closely linked with the production system. Thus, the Finnish forestry cluster includes an important industry for the production of machinery and equipment for all phases of activities, as well as engineering and consultancy services. Moreover, much of the present Finnish engineering industry arose in connection with the forestry sector and gradually diversified into other activities. In other words, the cluster has constantly been increasing the proportion of added value through more complex activities using more specialized know-how.

There are side linkages in at least five important areas: i) electricity generation; ii) chemical and mining activities; iii) marketing and logistics; iv) environmental industries, and v) related services. 


\section{The formation of a mature production cluster}

Figure 2 shows the evolution of exports from the Finnish forestry cluster during the twentieth century. As may be seen from the figure, up to the end of the nineteenth century the bulk of Finland's exports consisted of primary commodities with little processing, basically roundwood. These exports gradually began to diversify into activities involving higher levels of processing: first of all sawnwood and then, successively, plywood, furniture and wood products in general. The exports of such products reached their peak in the late 1950s, although they never exceeded US\$ 1 billion; as from 1920, the degree of processing increased, and fundamental importance was assumed by exports of wood pulp, then cardboard and paper and, within the latter category, increasingly sophisticated types of paper. Since 1960, these exports have together accounted for half the total value of the exports of the forestry cluster (currently, around US $\$ 2$ billion). After the Second World War, Finland began to export machinery for all the activities of the forestry cluster (planting, extraction and processing). The total value of such exports is currently close to US $\$ 1.5$ billion and is still rising. Finally, as from 1970 Finland began to export important chemical inputs for the forestry cluster which currently amount to US\$250 million.

On the basis of this analysis of the evolution of the Finnish forestry cluster, it may be asserted that the formation of a mature cluster goes through four stages (figure 3). In the first phase, the natural resource is extracted and exported with the minimum essential local processing; because of the high transport costs (for example, roundwood and some sawnwood). Almost everything else is imported: the bulk of the inputs, machinery and engineering services (except part of the production engineering services).

In the second phase, processing and export activities are initiated (such as wood pulp, cardboard and paper industries) and a start is made on import substitution with local production of some inputs and equipment (typically under license for the domestic market), while almost all production engineering services are provided locally, as are part of those connected with design.

In the third phase, the country begins to export some of the goods and services which it originally began to produce for import substitution purposes:
FIGURE 2

Finland: Evolution of the forestry cluster

Exports (millions of dollars)

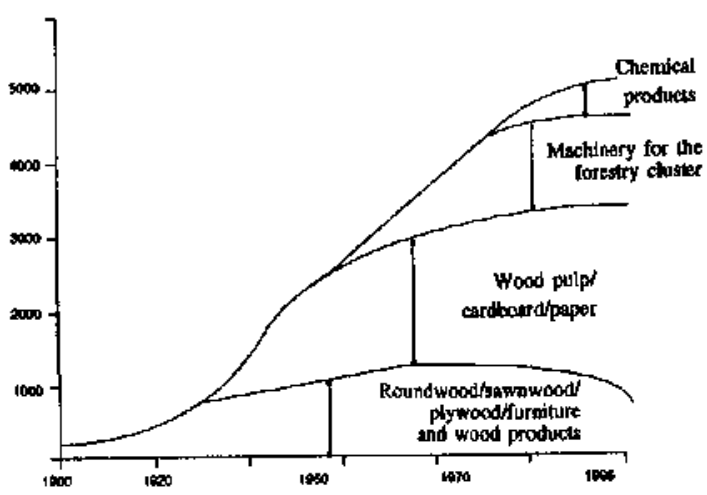

inputs and basic machinery for relatively undemanding markets (as for example, in the case of Finland, to the Soviet Union after the Second World War); the engineering services used are almost entirely of domestic origin, and further progress is made in the export of increasingly sophisticated processed goods (such as fine and special papers).

Finally, in the fourth stage (which began in the case of the Finnish forestry cluster in the mid1970s) all types of goods and services are exported; processed goods of great variety and complexity, inputs and machinery for demanding markets, design engineering services, and specialized consultancy services. In addition, domestic enterprises begin to invest abroad in the same area of activity.

What occurs in reality is of course much richer and less rigid than in analytical schemes. It may be that some activities "fall back" or "run ahead", but the foregoing pattern of evolution does indicate in its broad lines the typical evolution which is to be expected in the development and consolidation of a successful mature production cluster, that is to say, one capable of maintaining its competitiveness not only through its natural comparative advantages but increasingly through continual improvements in productivity. Without the constant accumulation of technological progress, the evolution of the cluster will become bogged down and will be limited to the "pure rents" of the extraction phase.

In the case of the Finnish forestry cluster, atthough most of the important technological advances were imported, at least initially, there were also 
FIOURE 3

Development of a production cluster

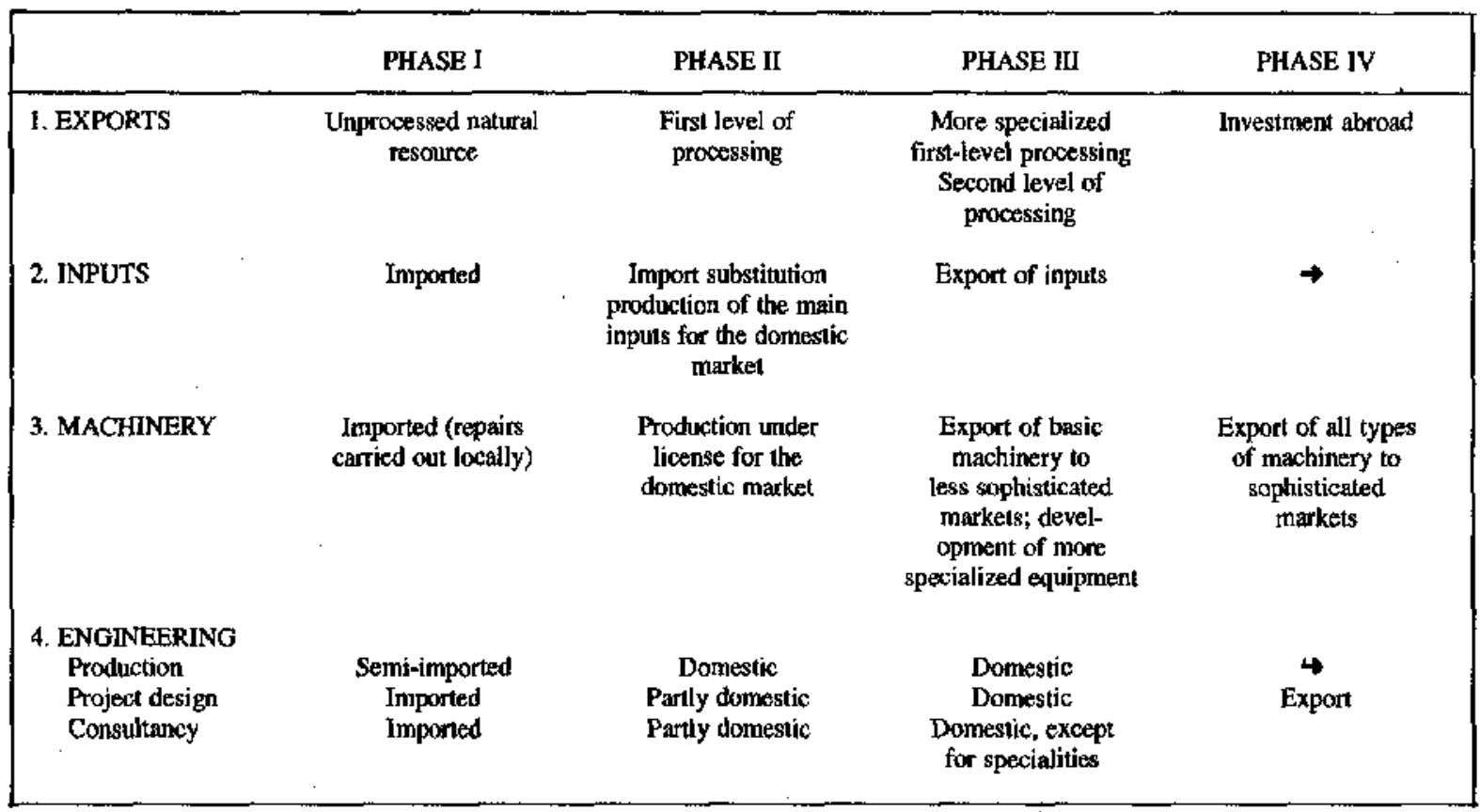

Finnish innovations resulting from learning by doing. These have tended to be small but ongoing innovations, so that they have become significant in the long run, but with the passage of time, because of the strong technological base -of consultancy firms, specialized universities and various research centers in the forestry field- and the close relationship between producers, suppliers and the technological infrastructure, significant domestic innovations have also been made. The Finnish forestry cluster is therefore on the world technological frontier, especially with regard to chemical products for the forestry area (Ojainmaa, 1994).

The foregoing review of the development of the technological base which made possible the growing modernization, specialization and expansion of this cluster makes it clear, however, that success is not automatic in these cases. There are many possibilities of failure, since the evolution is neither certain nor automatic. Although it is true that there was rarely any active promotion, there were chance events which were suitably exploited and turned out to be decisive. Thus, for example, the fact that Finland had to pay war reparations to the former Soviet Union created an insatiable demand for capital goods for the
Soviet forestry, paper and mining industries, and this subsequently aided Finland significantly in its first export stages, since it guaranteed a market for its equipment, which was still relatively unsophisticated and not internationally competitive. Thus, paradoxically enough, the war reparations were of decisive importance in the development and competitive maturity of this capital goods industry.

There have been many cases of failure or only linited success, however, due to the lack of such lucky impulses, ignorance of how to take advantage of them, or insufficient or ineffective promotional measures. Among the best known and most extensively studied cases of this type in the region is that of the Corporación Venezolana de Guayana (CVG). ${ }^{5}$ Although there is no doubt that this Corporation successfully promoted the exploitation of the natural riches of the region -especially iron ore, electricity

\footnotetext{
5 This paragraph is based on the evaluation made by león (1996) of the impact of the CVG on the development of activities relating to basic iron and steel, electricily and aluminium enterprises. The evaluation included in-depth interviews with 62 key agents: 32 from the CVG, seven from the political area, and 23 with entrepreneurs supposedly benefitted by the CVG.
} 
and aluminium- it was less successful in developing the activities of the related basic enterprises, both upstream and downstream. This was not due to any lack of promotional policies -these existed and included, inter alia, the establishment of industrial parks and supplier development programmes- but to the ineffective way in which they were implemented. Among other shortcomings, there was politicization, clientage, lax controls, lack of technical criteria, and little policy continuity, especially in the case of policies to promote competition. Consequently, the development of related activities was less than expected, and the enterprises set up often suffered from low levels of competitiveness and specialization, technological backwardness and a high degree of dependence on the basic enterprises. ${ }^{6}$ Leon's appraisat is particularly negative with regard to the metal products and machinery workshops supplying the basic industries and the failure to develop a scientific and technological infrastructure to support the technological updating and innovation of the activities of the production cluster that was supposed to grow up around the basic enterprises.

\section{Mature production clusters In the developed countries}

There is a very wide variety of mature clusters in the countries which are now developed, and by no means all of them are based on a natural resource. Since there is a relative abundance of natural resources in Latin America, however, we will go on to review

\footnotetext{
${ }^{6}$ More specifically, the high degree of dependence scems to have been due both to the State-oriented concept of development prevailing at the time -which reserved basic activities for the State sector and looked down on the role of private enterpriseand the low level of business capacity. Thus, "since the promotion of other activities did not elicit a suitable response from the private sector, the CVG was obliged to involve itself in areas where no other sector was willing to commit itself -both in areas of a private nature, such as hotels, housing construction, pulp and paper industries, tractor manufacture, etc., and in public-sector aress such as the construction of schools and hos pitals"; the CVG remained in possession of the enterprises that it set up, without transferring them to the private sector, and this further inhibited the development of that sector, causing it to adopt an attitude of merely following the CVG's lead, without laking any initiatives itself: "thus, the CVo was gradually taking on more and more responsibilities and areas of action, overstepping the dividing line between a strategy of promotion and one of execution" (León, 1996).
}

some clusters which grew up around an important natural resource.

In Norway, for example, there is an important production cluster around marine activity (Reve and others, 1992; Reve and Mathiesen, 1994). This cluster includes in particular maritime transport industries, fishery industries, and shipyards for the production of all types of vessels, including the most highly specialized tankers. There are also enterprises producing and exporting machinery and equipment for the fishery industry and the shipbuilding industry, as well as a wide range of services nelated with maritime activity in all its aspects (for example, marine insurance, shipbrokers, legal services, consultancy services, and research and development).

Because of Norway's abundant resources of hydroelectricity and natural gas, an important electrometallurgical cluster has also grown up in it. Denmark and the Netherlands, for their part, each have important dairy and stock-raising clusters and significant production of machinery and equipment for these activities, while a complete production cluster has arisen in the Netherlands for the production and marketing of flowers. Canada, and to a lesser extent Australia, have mature mining clusters which cover not only extraction and processing but also prospecting, the production of inputs and equipment, and the provision of related services. And such an apparently traditional activity as poultry rajsing has given rise to examples of some of the most complete and sophisticated clusters where (at least in the United States) the spearhead areas are not the manufacture of specialized machinery and equipment but the development of bio-technological advances to improve the fattening and egg-kaying capacity of the birds.

These mature complexes are marked by the generation of activities so solidly based that many of them have survived the disappearance or relative depletion of the natural resource which originally gave rise to them. For example, the Finnish mining industry gave rise to an important industry for the production of mining machinery and equipment, and today, although mining -the original core of the cluster- is no longer so important in the country, the production of mining machinery is one of its main export activities. Likewise, although the Netherlands continues to produce flowers, it also imports them for re-export: its main comparative advantage lies in the development of new varieties and the marketing of flowers throughout Europe and the rest of the world. 
Production clusters do not only arise in connection with physical goods, such as tangible natural resources, of course: they also include the provision of services connected with natural resources in the broader sense. Thus, for example, the tourism cluster was of fundamental importance for promoting the development of Spain after the war, on the basis of the country's abundant sun and beaches. According to each particular case, still greater importance may be assumed by eco-tourism (as in Costa Rica, Ecuador, Amazonia, etc.); adventure tourism (sailing down the rapids and channels of Chile, scaling the Andes, etc.); archaeological or historical tourism (in Mexico and Central America, Peru and Ecuador, etc.); medicinal tourism (in Cuba and other countries), and residential colonies for retirees from the developed world (in the Caribbean, Mexico, Central America, etc.).

In almost all successful clusters, an important element for strengthening and intensifying the linkages was suitable institutional complementation, sometimes of public origin (at the regional or state rather than the national level), but always including the associations of producers operating in the cluster. We already mentioned above the importance assumed for the development of the mining and also the agroindustrial sectors in the United States by the early establishment of highly specialized university courses on the relevant technology, with close links between the corresponding university departments and industry with regard to innovation. In this respect, the great importance of proximity to major university centres and highly qualified professional labour for the Silicon Valley (California) and Route 128 (Boston area) clusters is well-known. Similarly, the existence of training programmes has been vital for many other clusters, such as those in Emilia Romagna (Italy), Baden-Wurttemberg (Germany) and West Jutland (Denmark) in the developed countries and the clusters producing footwear (Valle Sinos, Brazil) and clothing (Ludhiana, India) in developing countries.

Centres providing services have also been very important in the progress of clusters. Thus, for example, the more than 100 state technology transfer centres, closely linked with the production cluster, have been vital for the development and production updating of the Baden-Wurttemberg industrial district. 'The services supply centre (CITER) has aided the development of the Emilia Romagna textile cluster through the provision of information on market trends, international fabric prices, availability of machinery and fashion trends; similar centres also exist for the footwear, agricultural machinery and construction industries. Emilia Romagna also operates centres for the promotion of exports and quality and has programmes for the development of suppliers. Private and public organizations with such functions have also been of decisive importance in almost all the emerging production clusters in developing countries.

Finally, a key role has also been played by the financial institutions, some of them highly specialized, which attend to the credit needs of various types of clusters, both in the developed and the developing countries. In this case, as in those referred to earlier, the generation and initial formation of the clusters was spontaneous and had little to do with any special institutional support, but their subsequent development was furthered both by the collective action of their members and by specific support policies applied by public bodies.

7 The analysis of this aspect is based on Schmitz and Musyck (1993) and Nadvi and Schmitz (1994). 


\section{IV}

\section{Incipient production clusters}

\section{in Latin America}

Are production clusters -even if only incipientgrowing up around natural resources in Latin America? The answer is obviously affirmative. Let us take a look at some examples.

\section{The oilseeds cluster in Argentina}

Our first example is taken from the agricultural and foodstuffs sector, which is of great importance in the region. It refers to the oilseeds cluster in Argentina (De Obschatko, 1997). As figure 4 shows, this cluster generates $25 \%$ of Argentina's exports and has grown extremely rapidly: its exports increased by a factor of 17 between the beginning of the $1970 \mathrm{~s}$ and the beginning of the $1990 \mathrm{~s}$, when their value amounted to US\$ 3.4 billion. This cluster, which is of prime importance for Argentina, utilizes the comparative advantages for agricultural production offered by the Argentine pampas and a relatively close outlet to the sea. Its rapid growth was driven by: i) the doubling of the international prices of oilseeds and vegetable oil, which made the production of both these items very profitable; ii) a sharp increase in the yield per hectare over the last twenty years (at the rate of $2.2 \%$ per year in the case of soya beans and $4.0 \%$ in that of sunflower seeds), and iii) the feasibility of double cropping (wheat in winter and soya beans in the rest of the year), which doubled the yield of the land.

The complex is now quite mature and has backward, forward and side linkages. With regard to forward linkages, there is an important processing industry which takes the agricultural inputs (soya beans and sunflower seeds) and turns them into oil and by products, doubling the value per ton (from US $\$ 245$ to US\$ 485). The next phase (marketing) includes such important services as storage, transport and shipping.

Both the agricultural and the processing phases have important backward linkages. The agricultural phase has generated a demand for machinery, herbicides and oilseeds which has given rise to domestic indrstries producing equipment, biotechnology and inputs. A domestic industry has also been set up (under license from international equipment manufacturers) which produces $90 \%$ of the machinery required by the processing plants. Moreover, the fact that these plants need to ensure an adequate and timely supply of raw materials so that they can maintain full utilization of their facilities has given rise to agreements between the processing plants and the agricultural producers, under which the former provide the producers with financing for inputs and with technical assistance in the dissemination of modern technologies. Finally, the strong and ongoing increase in yields is largely due to the services offered by agricultural research centres such as the University of Buenos Aires, which have undertaken the adaptation and improvement of imported seed varieties.

The cluster has passed through three stages. In the first phase (the agricultural phase), which lasted ten years up to 1984, exports of oilseeds increased by a factor of 200 , reaching a value of US\$ 600 million per year. In the second phase (the processing phase), which had already begun during the previous stage, there was also notable growth: exports of vegetable oils doubled, and now have a value of around US\$ 1.5 billion. During this second stage agreements were signed between the processing plants and the producers under which the latter were provided with technology and with financing for inputs, in order to ensure an adequate and timely supply of raw materials for the industrial plants.

There were four decisive factors in this strong development of the industry: i) an increase in the international prices of vegetable oils; ii) an effective exchange rate which was more favourable for industrial exports than agricultural exports, since the tax on agricultural exports was higher than that on exports of oils; iii) the rapid introduction of the most advanced technology in the Argentine processing

\footnotetext{
${ }^{8}$ Even more modern than that used in the United States.
} 
FICURE 4

Argentine: The oilseeds cluster ${ }^{a}$

Beckwand linkages

Forward linkages

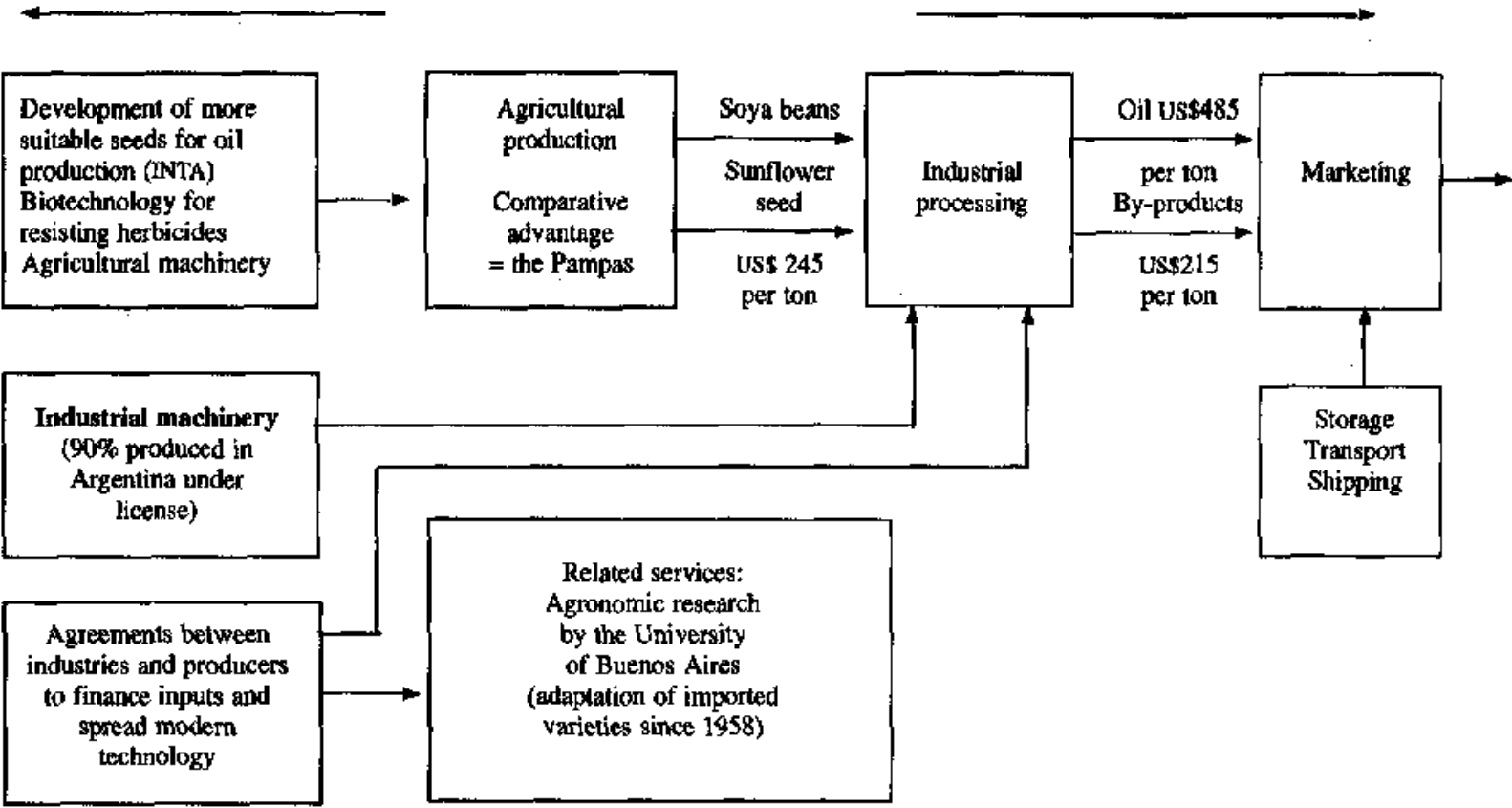

${ }^{a}$ Generates 25\% of Argentine exports.

plants, which now use chemical solvents for the production of oils instead of the outdated and inefficient technology based on the use of presses, and iv) improvements in productivity (by a factor of 10 ) through learning and full use of economies of scale (in fact, the amount of oil produced increased by a factor of eight, while the number of workers employed in the processing plants went down by $20 \%$ ).

The third stage was marked by a rapid increase in marketing activities. Two phenomena were important in this phase. On the one hand, there was the deregulation of many activities which were essential for marketing, such as railways, transport and port activities. On the other hand, and also partly due to deregulation, there was a cycle of heavy investments in warehousing, transport, railways, ports and private shipping facilities.

The international competitiveness of the Argentine oilseeds cluster is shown by its success in penetrating the most demanding market, that of the member countries of the Organization for Economic Cooperation and Development (OECD). It may be seen from figure 5 that Argentina occupied second place in OECD imports of oilseeds and related products in 1994, second only to the United States and tying with Brazil and Canada. Although Argentina's share in the OECD market for oilseeds and fodder is below that of Brazil, its share in edible oils is much greater ( $5 \%$ compared with $1 \%$ ). On the other hand, although Argentina produces machinery for the oilseeds cluster, it is not yet a significant exporter of food processing machinery, as are the United States (with 10\% of the OBCD market) or Canada (with less than $2 \%$ ). The next step which may be expected is therefore the export (and not just production for the domestic market) of food processing machinery.

Indeed, as may be seen from figure 6, Argentina has already begun to export such equipment, beginning with the Latin American market, where it has a share of $2 \%$. Although this share is only modest, it is nevertheless bigger than that of Canada, which, as we have seen, is competitive in the OECD (probably in the United States market) but much less so in Latin America. Of the Latin American countries, Brazil has 
FOURA 5

Shares of ealected countries in OECD Importe of olleseda and related producte, 1994

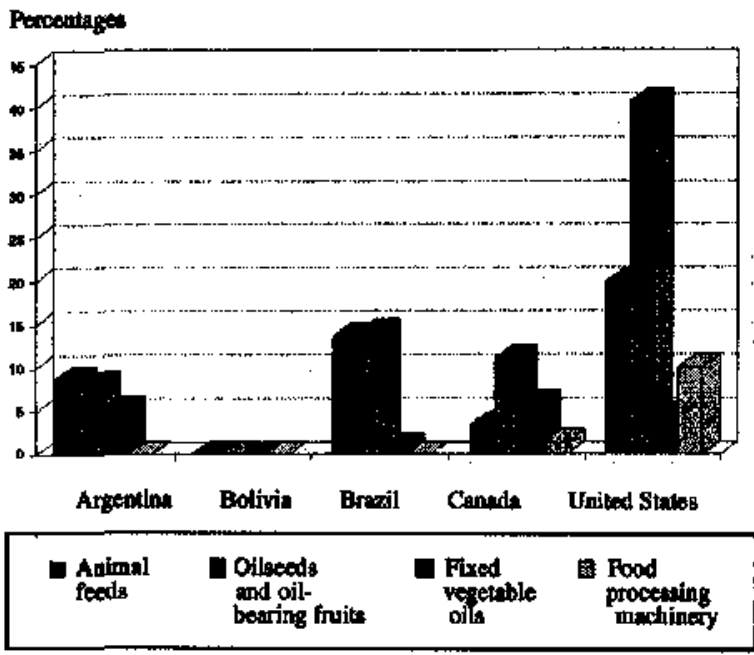

the biggest share in the regional market (with $6 \%$ ), although this is far behind the United States (with almost $30 \%$ of this market).

This suggests that first of all machinery is produced for domestic industry (if the demand is sufficient). Afterwards, with more experience, simple machinery can be exported to the closest markets while the production of more sophisticated machinery for domestic industry is begun. Finally, in a subsequent stage, simple machinery begins to be exported to all markets, and specialized machinery begins to be exported to the closest markets which can be served from the company headquarters.

\section{The mining cluster in Chile}

Another production cluster which is quite developed, although not completely mature, is the industrial cluster which has grown up around the mining sector in Chile.

This cluster has grown up around the extraction of copper, in which the country has strong comparative advantages, for Chile has over $25 \%$ of world copper reserves -which makes it a kind of Saudi Arabia of the copper industry- and it also has mines with relatively high metal content (around $2 \%$ ). Furthermore, because of the geographical configuration of the country, in which the mountain range of the Andes is close to the sea, the transport costs to inter-

\section{FICAURE 6}

Shares of eslectied countries in Latin Amarican Imports of olfeseds and reluted products, 1994

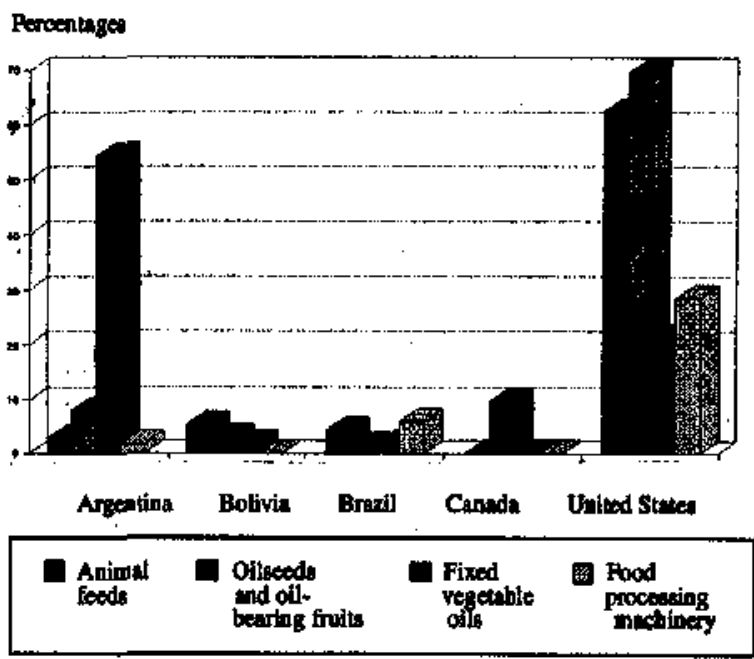

national markets are relatively lower than in other countries.

The cluster already displays important forward and backward linkages (see figure 7). ${ }^{9}$ The copper ore as extracted from the mines has a metal content of the order of $2 \%$ and a value of around US\$10 per ton. After a process of smelting and generally also of refining, the ore is converted into copper of over $99 \%$ purity, worth some US $\$ 2,000$ per ton. In other words, the processing increases the copper content by a factor of 50 but raises the value by a factor of over 200. Most of the refined copper is exported directly, but quite a significant part is converted into wire and other products which are then exported. Greater maturity of the production cluster would involve the promotion of these latter activities.

The backward linkages are just as highly developed, if not more so. Only $15 \%$ of the cost of extracting copper corresponds to labour; the remaining $85 \%$ represents derived demand for potential domestic suppliers. This $85 \%$ is broken down into $50 \%$ for inputs such as explosives and chemicals; $25 \%$ for capital goods such as drills, crushers, trucks, bulldozers, etc., and $10 \%$ for engineering services (basic engineering, project engineering, and structural engineering). Domestic production currently supplies

\footnotetext{
${ }^{9}$ The analysis of this topic is based on Duhart (1993).
} 
FIOURB 7

Chlle: An Inciplent mining cluster based on copper

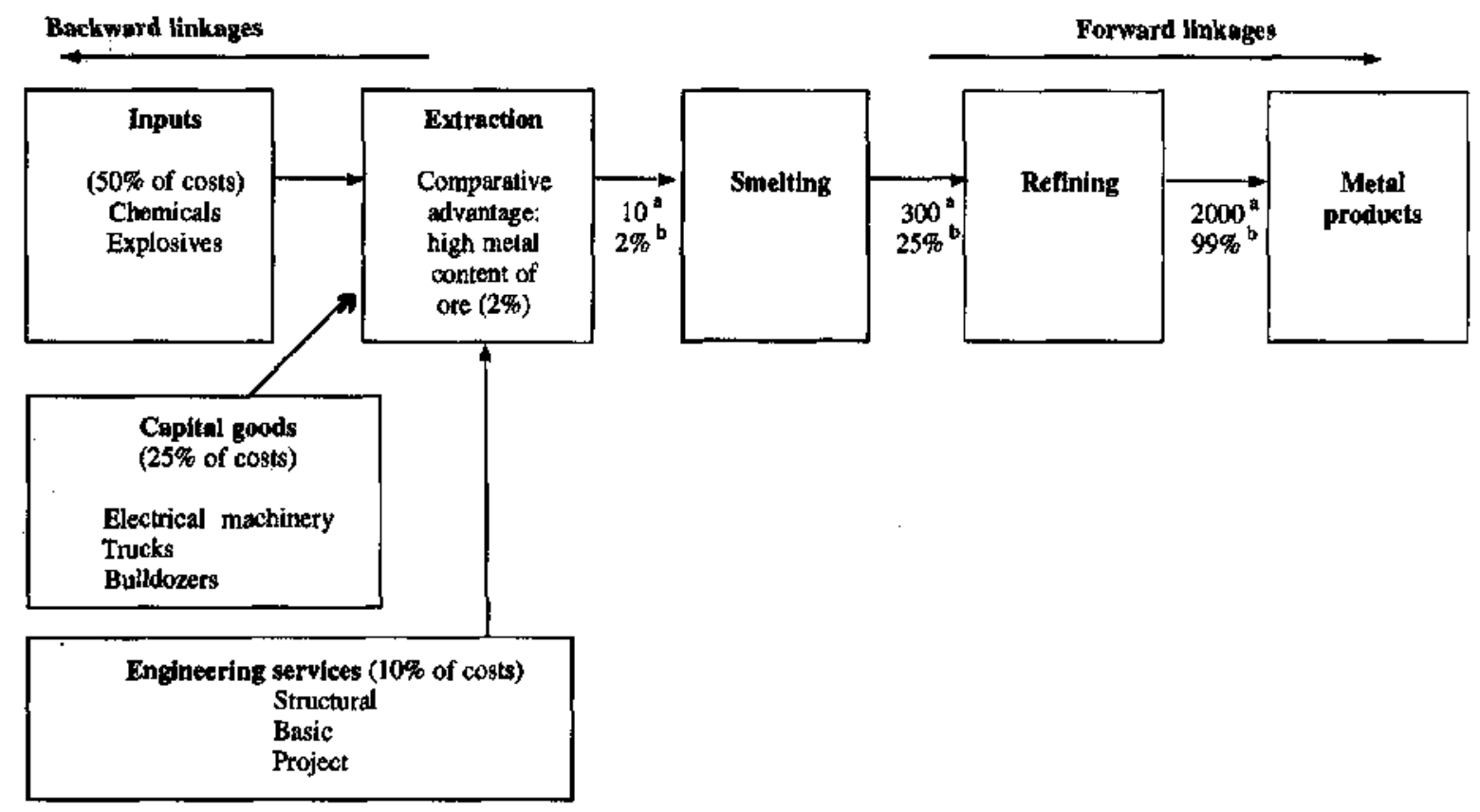

Sowrce: ECLAC, on the basis of official data.

- Dollars per ton. ${ }^{\circ}$ Copper content.

two-thirds of the inputs, $40 \%$ of the equipment (especially replacement equipment) and $75 \%$ of engineering services. In other words, $60 \%$ of the cost of inputs, machinery and engineering services (i.e., $60 \%$ of the potential backward linkages) is for goods and services provided by domestic industry.

As might be expected, this process of replacement of imports by domestic production has been advancing with time. Thus, 40 years ago, in 1955 , le'ss than $25 \%$ of these linkages involved goods and services provided locally: $40 \%$ of inputs (compared with $67 \%$ at present), only $5 \%$ of machinery and equipment (in coptrast with $40 \%$ today), and less than $10 \%$ of engineering services. There has been noteworthy progress in quantitative terms and in adding value to production, especially in the areas making use of know-how and technology.

It should be noted that only part of this process of substitution of inputs and equipment was spontaneous. Much of it was due to the strong impulse provided by an active policy in favour of domestic products. The success of this policy may be seen by the fact that today domestic industry is competitive with imports, without enjoying any significant preferences.

Indeed, a recent study (Ritter, 1996) concludes that the Chilean capital goods industry for the mining sector is not far behind that of Canada in terms of its development. It is estimated that domestic industry provides $80-90 \%$ of the mining machinery of a low level of technology (the same percentage as in Canada); $30-40 \%$ of the machinery of medium technological level (compared with $40 \%$ in the case of Canada), and $20 \%$ (compared with $40 \%$ ) in the case of more specialized machinery of a high technological level (figure 8). Figure 9 provides a comparison of the production clusters of the two countries as regards their shares in OECD imports of copper and related products in 1994. It may be seen from the figure that Canada has a much more highly developed production cluster than that of Chile, with a substantial share in $O E C D$ imports not only of copper (where Chile's share is bigger) but also of wire and wirework, metalworking machinery, and civil engineering machinery and equipment. If we Jook at Latin American imports of the same items, however 
FIGURE 8

Relatlve development of capltal goods Industries for the mining sector: a global hypothesle or appralsul a

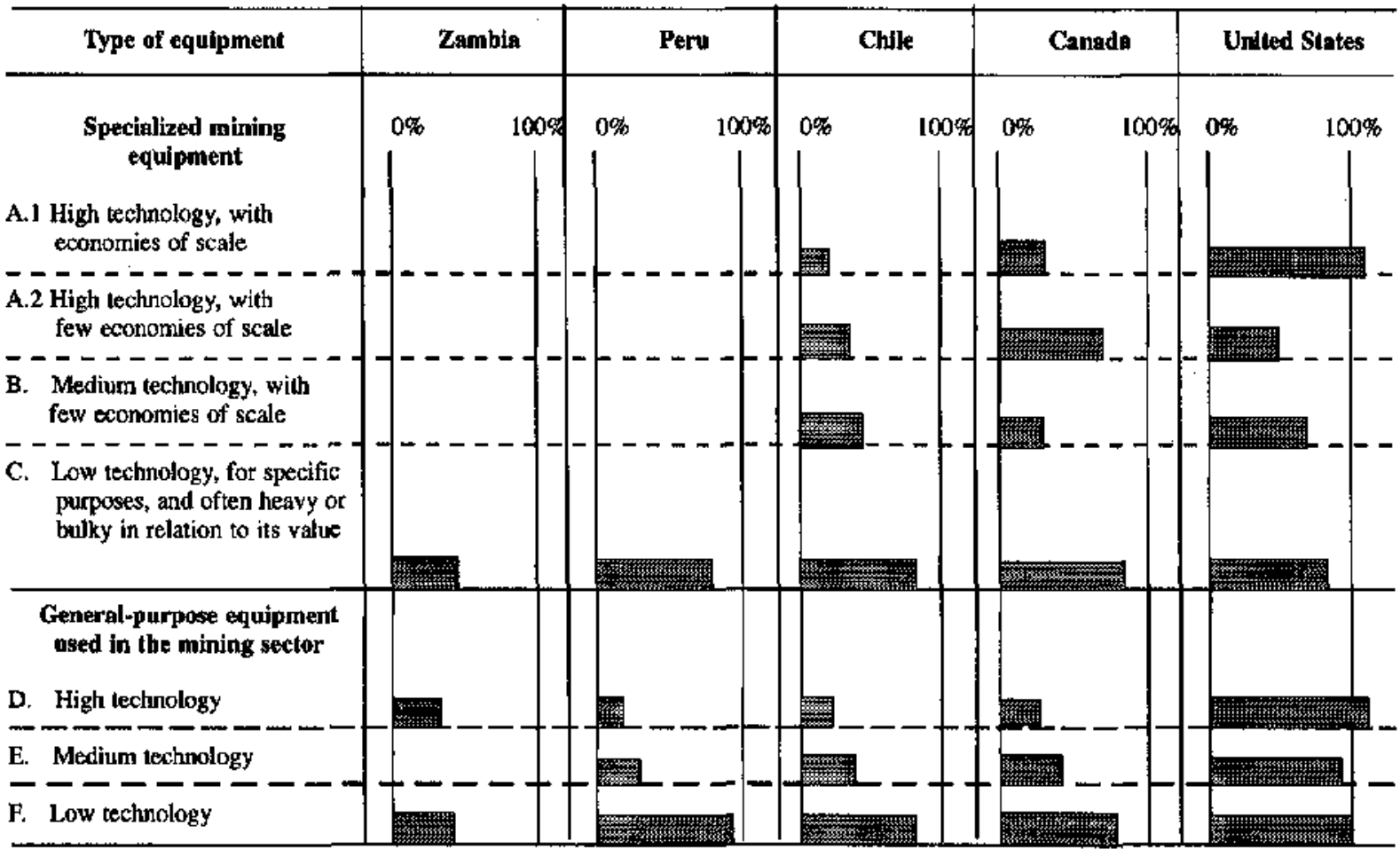

Source: Ritter (1996).

- The bars indicate the percentages of the total volumes of capital goods used by the national mining industry and provided by the domestic equipment manufacturing industry.

(figure 10), we see that Chile is beginning to export wire and wirework and civil engineering machinery and equipment: Chile's share in this Latin American market is not far below that Canada and higher than that of Australia. This confirms the tendency already noted to begin by substituting imports, then to export to the closest markets, and later export to more distant and demanding markets, and it also confirms not only the relatively high degree of complexity of Chile's production of copper-related goods but also its great future development potential.

Moreover, as the mining machinery industry usually calls for some degree of proximity to the mines (for underground mining, at least, calls for a great deal of adaptation of the equipment to local mining conditions), it can be expected that there will be a considerable boost in the future for the Chilean industries producing capital goods for the mining sector. On the one hand, the large volume of invest- ment foreseen in the medium-term future for the mining sectors.of Argentina, Bolivia, Penu and also Chile guarantees strong demand for such equipment, and on the other, Chile is the only one of these countries with a more or less developed industry of this type close to the mining areas.

It is also worth noting that Chilean engineering service enterprises are exporting their services abroad and have even begun to export technology. Outstanding examples of this are the modifted furnace developed and patented by Codelco, which has been sold to smelting plants in Mexico, Peru and Zambia, and the bacterial leaching process developed by the Pudahuel mining company, which has also been sold abroad.

In spite of these advances, however, the rate of progress is still very low for a country which has the biggest reserves of copper in the world. Indeed, the research and development effort in the mining sector 
PJGURE 9

Shares of ealected eountries In CECD imports of copper and related products, 1994

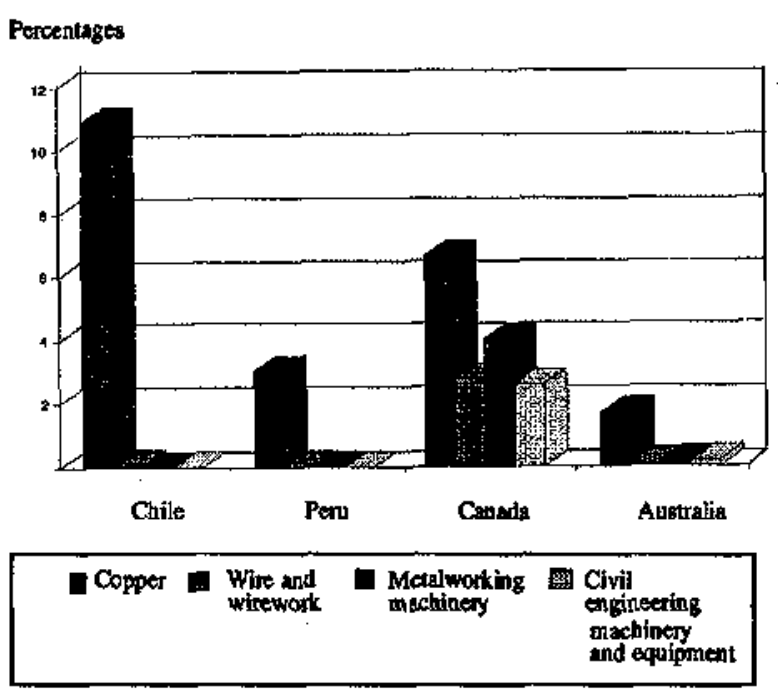

is very insufficient: the technological centres engaged in mining research employ some 150 specialized professionals, and their budget is around US\$ 4 million per year, which is much less than $0.1 \%$ of the value of the country's mining exports. Although it is also necessary to add to this figure the research being carried out in the universities and the development projects financed from various technology funds, it is nevertheless clear that the amounts are insignificant for the main industry of a country which is the biggest copper exporter in the world. It may be recalled that the developed countries devote nearly $2 \%$ of their GDP to research and development, and even countries which make intensive use of natural resources, such as the Scandinavian countries, spend more than $1 \%$ of their GDP on activities of this type connected with natural resources.

\section{Other major production clusters}

Other important examples of incipient production clusters in Latin America are those connected with the iron and steel industry and forestry activities. Figure 11 shows the shares of three Latin American countries, two recently industrialized Asian countries, and two developed countries (Japan and Germany) in OECD imports of types of goods connected with the iron and steel cluster. First, we see that Germany has the most complete and mature
FIOURE 10

Shares of selectod countries in Lalin American Imports of coppor and related products, 1994

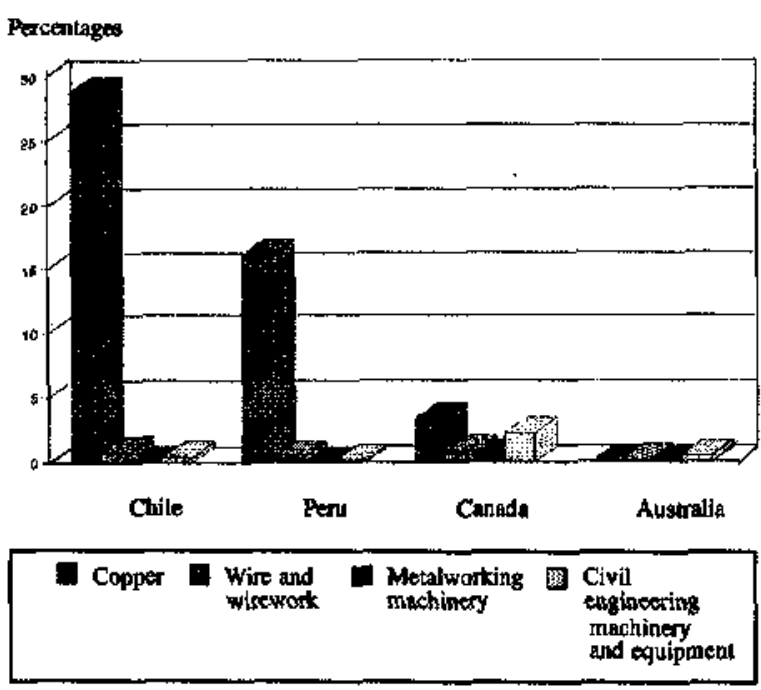

cluster. It does not export iron ore, of course, but processes the whole of it. Although Japan lacks significant natural resources in this field it nevertheless has a highly developed cluster, although not so much so as that of Germany. Since it lacks raw materials of its own and has a processing industry which depends on imports, Japan has specialized above all in the production and export of metalworking machinery, which is undoubtedly the phase that makes the most intensive use of specialized know-how and technology.

Second, Brazil -a country with abundant iron ore reserves- has a very high share in OBCD imports of this raw material, followed by unworked iron and steel, but it has only a low share in the categories which are more demanding in terms of technology. Furthermore, Brazil's share in OECD imports of metal manufactures and metalworking machinery is even below those of South Korea and Tawan, whose iron ore endowment is very scanty. This shows that an important industrial cluster can be developed, through imports, even without having the natural resource on which is based.

Third, it may be observed from figure 12 that in the case of the Latin American market, Germany's share is much lower, whereas that of Brazil is much higher in all categories, even the more complex ones. Thus, in all categories except machinery Brazil's share is higher than those of Japan and Germany, and 


\section{Foune 11}

Shures of solectad countrias in OECD Importo of tron ore, iren and twell and nelated products, 1994

Percenirges

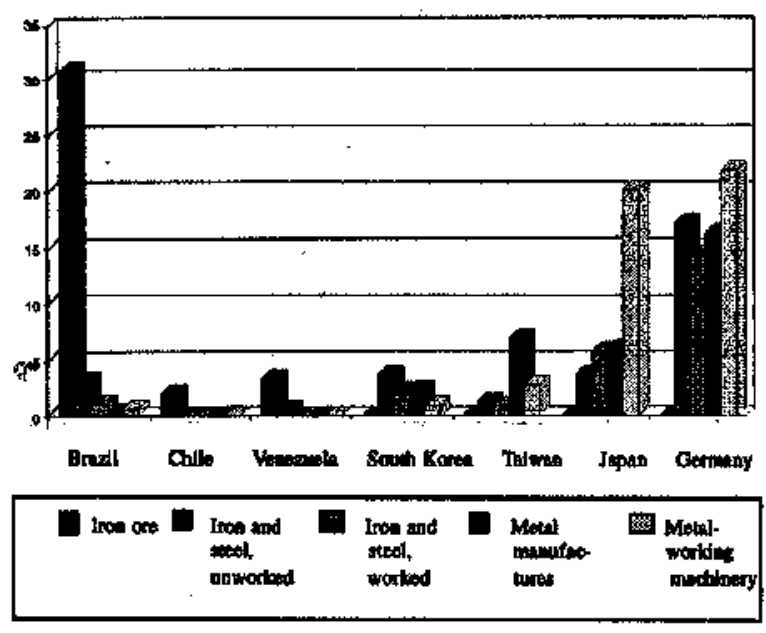

FICURE 12

Shave of selectad countrice In Latin Amorican Imports of iron ore, Iron and ateol and related producte, 1804

Pereentages

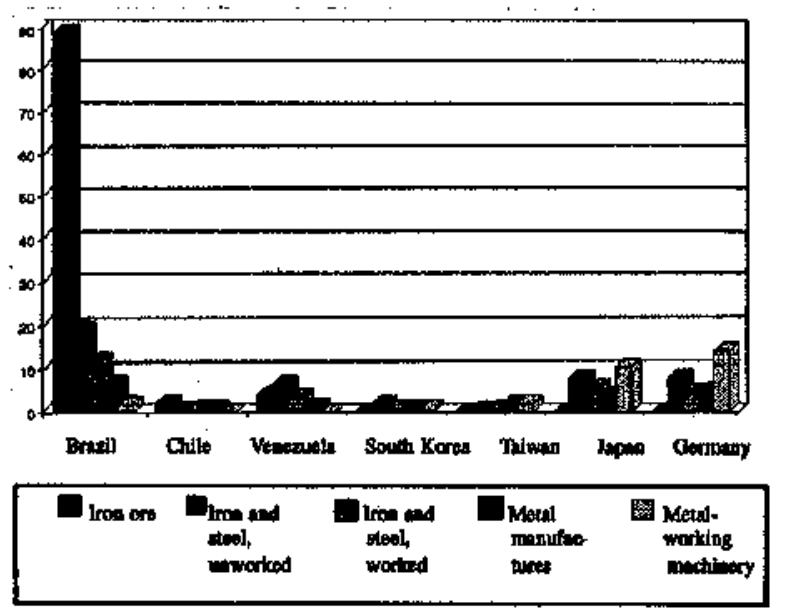

even in the case of machinery its share is higher than that of South Korea and almost equal to that of Taiwan. This suggests once again that the natural evolution of a production cluster is to progress from import substitution to exports, but starting with the closest or least demanding markets and only later going on to more distant markets. Venezuela, too, is
FOURE 13

Shares of selected countrioa in OECD.

import of wood and rolated producte, 1994

Percentengen

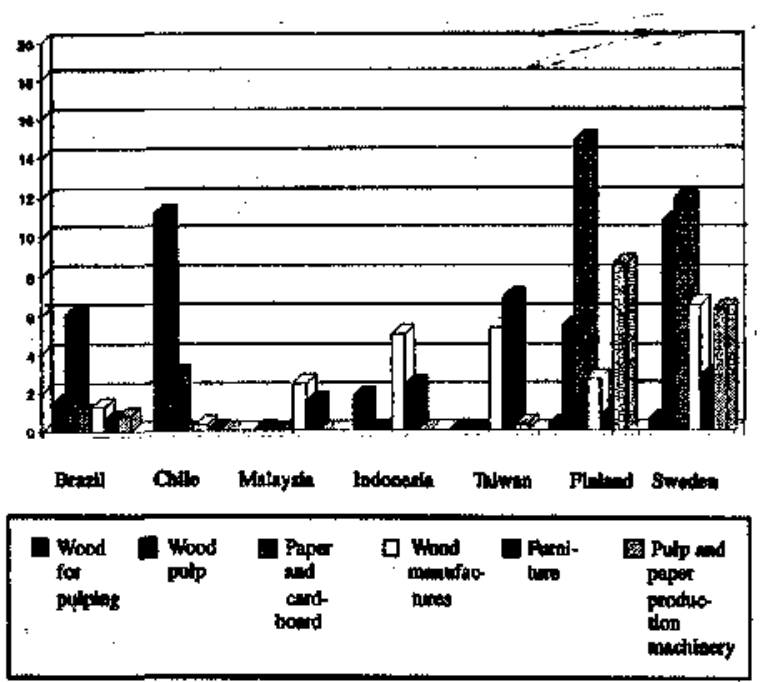

beginning to make its presence felt in the Latin American market, with a share which is higher than that of South Korea in all categories and higher than that of Taiwan in the less complex categories.

Figure 13 shows the share of forestry products in the OECD's imports in 1994. Finland and Sweden have the most complete and highly developed production clusters, while Brazil, Chile, Malaysia, Indonesia and Taiwan also have a certain international presence, although Taiwan does not have forestry resources of its own. It may be noted that there has been specialization in idifferent niches, even within the same branch: for example, Sweden has concentrated on expensive furniture of outstanding design, while Taiwan has concentrated on mass production. In spite of Sweden's greater specialization in high-quality fumiture, however, the total value of Taiwan's exports of fumiture was double that of Swederi. This shows that a niche of bigh value and quality is not always that which registers the highest volume.

Comparison of figures 13 and 14 shows that since 1977 the forestry clusters of the developing countries have been gaining shares in the OECD market at a rapid rate, whereas Sweden's shane has gone down sharply. The development of the Brazilian and Chilean clusters is even more striking if we look at their share in Latin American imports in these cate- 
Foúk 14

Shares of eelectod countries in OECD

Imports of wood and related products, 1977

Percentages

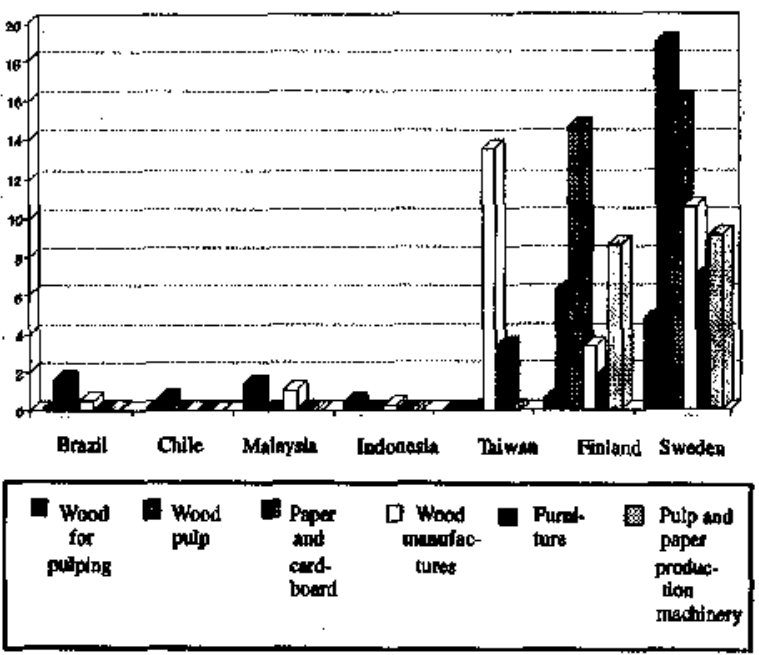

gories (figure 15). The development registered by Chile and above all Brazil is very noteworthy. Brazil's share in Latin American imports of wood and related categories dominates in all categories (except wood pulp, where Chile leads) and is much higher than that of Finland and Sweden: indeed, its share in the Latin American market for pulp and paper machinery, as well as the market for paper and
FGURE 15

Shares of selected countries in Latin American Imports of wood and relatiod products, 1994

Percentage:

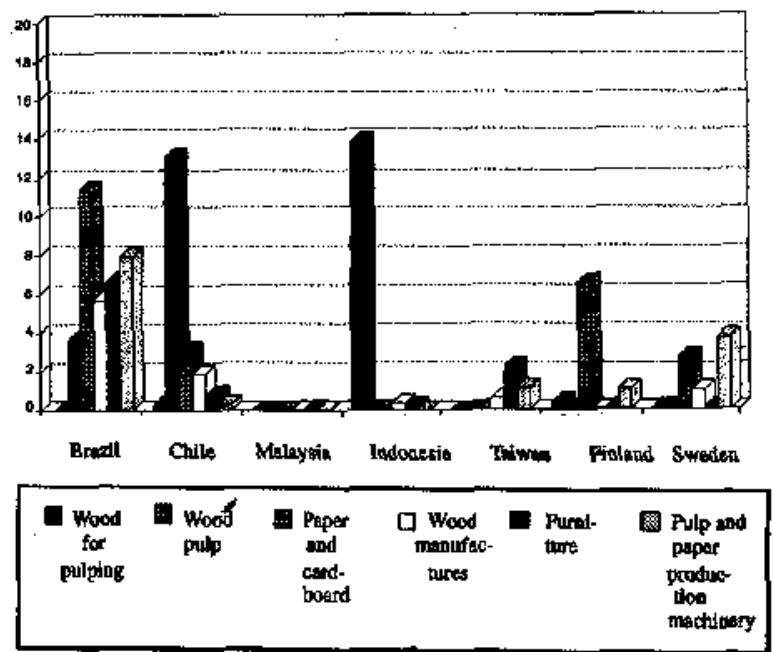

cardboard, is greater than that of Sweden and Finland together. Chile's share, for its part, is greater than that of Sweden, except in pulp and paper machinery. This highlights the big advances that have been made by the forestry clusters of Brazil and Chile, which still have a great deal of potential for developing their participation in the bigger and more demanding markets of the OECD.

\section{From spontaneous evolution}

\section{to promotion policies}

In the previous section we showed the important role played by the development of natural resource-based production clusters in many countries which are well endowed with such resources and are now developed. A similar development strategy to promote the consolidation of the as yet incipient clusters based on Latin America's rich endowment of natural resources would provide the region with an obvious development potential.

\section{If this development ls already taking place naturally, then why promote it?}

The answer is that the promotion of such a strategy would help the region to grow at much faster rates than the spontaneous or historical ones, and thus reach the goal earlier. In fact, it is a question of exploiting the great advantage of late development: broadly speaking, it is already known which direction 
to take, and such promotion is therefore perfectly feasible. There is no question of a voluntaristic or ahistorical type of promotion, or of one which goes against the market forces. On the contrary, since it follows the direction of the natural evolution of the market forces, what we are doing is anticipating the market and thus accelerating development.

It is important that all the economic agents should be collectively aware of the virtues of the strategy, for this awareness would be equivalent to a strategic planning process which unites wills and coordinates efforts, thus reducing uncertainty, operating at all times closer to the production frontier, maximizing yields, and, ultimately, multiplying the accumulation and efficacy of the factors of production.

\section{But when all is agid and done, how important can natural resource-based production clusters be?}

It is often considered that the global impact of these clusters is only limited, since the core (extractive) activity often has relatively little weight in GDP. This reasoning is deeply mistaken, however, since it concentrates exclusively on the direct impact of the clusters.

Thus, for example, Meller (1996) estimates that the whole of Chilean exports, the great majority of which make intensive use of natural resources, generate only $10 \%$ of employment directly. When the indirect employment generated by these exports is included, however -that is to say, the employment generated by the activities involved in processing, marketing and transporting these exports (the forward linkages) and the activities providing them with inputs, capital goods and engineering and consultancy services (the backward linkages)- the amount of employment is more than doubled. It is estimated that the employment generated indirectly by the backward linkages is $6 \%$ of the national labour force, while that generated indirectly by the forward linkages is a further $7.5 \% .^{10}$ Furthermore, thanks for the foreign exchange earned by these exports (and products with a high content of natural resources usually are exported), resources are made available for buying imports, which has a substantial additional effect on

10 With regard to the basis for the figures given in this paragraph, see Díaz and Ramos (1998). employment. In fact, unlike what occurs with import substitution, each dollar of exports, by making possible a dollar of imports, generates additional revenue for the State which offsets the anti-export bias of economic policy. This bias is equal to the $15 \%$ tariff (the average for the region) levied on imports, which are ultimately financed by exports. If this extra fiscal revenue were invested, it would generate an additional $10 \%$ of employment (on the assumption that each US $\$ 30,000$ creates one good, high-productivity job). The total employment of the cluster of activities developed around exportable natural resources in Chile would therefore account for around one-third of the total employment in the country, which is more than three times the direct effect. The true impact of the cluster on the national economy would thus be extremely important.

\section{How should production clusters be promoted? ls it a question of "picking winners"?}

The experience of mature clusters in developed countries indicates the direction which our development could follow. Although history never repeats itself completely, the path followed by the now-developed countries which have abundant natural resources gives an idea of the direction that Latin America is should follow (or not follow). We must take advantage of this knowledge in order to decide how best to speed up the maturity of the incipient production clusters of the region.

Thus, comparison of the incipient natural resource-based Latin American production clusters with similar clusters which are now mature in the developed countries suggests the following measures:

a) To identify, in conjunction with the private sector, the development potential of the activities supplying inputs and equipment, as compared with that of the extraction and processing activities; of processing activities of growing complexity; and of the related services, including in particular engineering and consultancy services. It is not a question, of course, of channeling investment directly to these activities, along the lines of the former Soviet GOSPLAN, but of carrying out a strategic planning exercise among the different economic agents in order to make a systematic and collective analysis of the investment opportunities available in the relevant production cluster. 
b) To identify the activities of the production cluster which require more foreign investment, because of the advanced nature of their technology, their access to international markets, or the amounts of resources involved, and to guide national efforts to attract the most suitable transnational corporations to the country. Already in the 1990 s there has been a sharp increase in foreign direct investment in Latin America. Such investment opens up new opportunities for producers in the region to become suppliers of transnational corporations not only for the domestic market but also, possibly, for international markets. However, not all foreign direct investment has the same potential for generating linkages, externalities or vital technological learning, and it is likely that the transnational corporations are not fully familiar with the local opportunities. This justifies efforts to attract, not so much foreign direct investment in general, but the corporations and types of foreign direct investment which are of most interest for the development of the incipient production clusters of the region."

c) To identify the key technologies for developing the production cluster and to promote the local mastery and updating of those technologies through selective policies for the promotion of research and development, both in domestic enterprises and in research institutes, as well as promoting the updating and adaptation of technology through missions abroad, promotion of licenses and joint ventures, and programmes for the co-financing of consultancy activities in respect of key technologies.

d) To identify the infrastructural needs of the cluster in the short, medium and long term, especially in the areas of greatest public interest and responsibility: physical infrastneture, scientific and technological infrastructure, and buman resources infrastructure (especially middle-level technicians, specialized technicians and professionals).

Although "hard" instruments could be used for these purposes (that is to say, direct incentives or coercion), it is considered that it would be sufficient, and would be more in keeping with the current spirit, to use "soft" instruments based on mutual agreement and inducement rather than coercion, except of course in respect of the physical, technological and

11 See Battat, Frank and Shen (1996), especially with regard to the potential offered by transnational corporations for the development of domestic suppliers in the region. human resources infrastructures, since the latter are mainly the responsibility of the public sector, so that there is no option but to plan and order the allocation of its limited resources among its many commitments.

At the same time, it must be acknowledged that speeding up the maturity of the clusters is indeed a form of "picking winners", but not in the pejorative sense of making a voluntaristic choice without adequate basis. Instead, it is simply a question of making a reasonable bet based on past development tendencies and thus speeding up what the market will in any case have to do for itself. Indeed, one of the advantages of late development is that it is possible to learn from the experience of others and thus jump over unnecessary stages. Specifically, what is advocated here is to learn from past experience and promote those activities which have tended to arise spontaneously on the basis of natural resources in the countries which are now developed and are rich in such resources. It therefore means going with the market, not against it.

Nevertheless, it must be emphasized that this strategy is a wager, and there is no absolute guarantee of success. As already noted in our analysis of the Corporación Venezolana de Guayana, the lack of promotion may mean failing to take advantage of important opportunities, but there is also a danger of failure if one goes to the other extreme of a high degree of dependence, through failing to distinguish between promotion and paternalism. Even so, we consider that this is a reasonable bet based on our capacity for learning from the past in order not to depend exclusively on spontaneous developments and chance or providential occurrences.

Finally, it should be noted that this strategy for industrialization on the basis of natural resources is not a panacea but a valuable instrument in the present stage of development of the region, which is faced with the challenge of turning its present endowment of natural resources - currently abundant, but ultimately limited-into a means of unrestricted growth. It is not a question of taking the place of the market, but of speeding up its action and achieving in 40 or 50 years what took a hundred years to occur spontaneously in the countries which are now developed and which had plentiful natural resources. It is this approach which will enable us to achieve rapid rates of economic development, much higher than those of the past.

(Original: Spanish) 


\section{Bibliography}

Auty, R. (1994): Industrial policy neform in six large newly industrializing countries: The resource curse thesis, World Development, vol. 22, No. 1, Oxford, U. K., Pergamon Press, January.

ADB (Asian Development Bank) (1997): Emerging Asia: Changes and Challenges, Manila.

Baldwin, R. E. (1963): Export technology and development from a subsistence level, The Economic Journal, vol. LXXIII, Cambridge, U. K., Royal Economic Society, March.

Bartam B., S. Bunker and D. O'Heara (1994): States, Firms and Raw Materials: The World Economy and Ecology and Aluminum, Madison, WI, University of Wisconsin Press.

Battat, J., I. Frank and X. Shen (1996): Suppliers to Multinationals: Linkage Programs to Strengthen Local Companies in Developing Countries, Foreign Invest. ment Advisory Service occasional paper No. 6 , Washington, D.C., World Bank, Foreign Investment Advisory Service.

Bellandi, M. (1996): El distrito industrial, Estudios territoriales, vol. 20, Madrid, Ministerio de Fomento.

Bianchi, P. (1992): Competencia dinámica, distritos industriales y medidas locales, "Industrialización y desarrollo tecnologico" series, No. 13, LC/G.1752, Santiago, Chile, Economic Commission for Latin America and the Caribbean (ECLAC).

Borges Méndez, R. (1997): The new geographical economics, natural resource-based development and some policy challenges for Latin America, Santiago, Chile, ECLAC, April, mimeo.

David, P. and G.Wright (1997): The origins of American resource abundance, All Souls' College, Oxford and Stanford University, mimeo.

De Obschatko, E. S. (1997): Articulación productiva a partir de los recursos naturales: el caso del complejo oleaginoso argentino, Documento de trabajo, No. 74, Buenos Aires, ECLAC Buenos Aires Office.

Díaz, A. and J, Ramos (1998): Apertura y competitividad, in R. Cottázar and J. Vial (eds.), Construyendo opciones: propuestas económicas y sociales para el cambio de siglo, Santiago, Chile, Economic Research Corporation for Latin America (CIEPLAN)/Dolmen Ediciones.

Dini, M. (1992): Capacidad competitiva de las pequeñas empresas italianas. Análisis crtico de la teoría de los distritos industriales en un marco de economía abierta, "Industrialización y desarrollo tecnologico" series, No. 13, LC/G.1752, Santiago, Chile, ECLAC.

Duhart, J. (1993); Impacto tecnológico y productivo de la minería del cobre en la industria chilena 1955 . 1988, in ECLAC, La transformación de la producción en Chile: cuatro ensayos de interpretación, "Estudios e informes de la CEPAL" series, No. 84, LC/G.1674-P, Santiago, Chile, ECLAC. United Nations publication, Sales No. S.93.II.G.4.

Hirschman, A.(1957): The Strategy of Economic Development, New Haven, CT, Yale University Press.

(1977): A generalized linkage approach to development, with special reference to staples, Esssays on Economic Development and Cultural Change in Honor of Bert F. Hoselitz, vol. 25, supplement, Chicago, IL, University of Chicago Press.

Innis, H. (1954): The Cod Fisheries. The History of an International Economy, Toronto, University of Toronto Press.

(1962): The Fur Trade in Canada, Toronto, University of Toronto Press.

Krugman, P. (1995): Development, Geography and Economic Theory, Cambridge, MA, MIT Press.

León, L. V. (1996): Historia de la experiencia empresarial de la Corporación Venezolana de Guayana, Caracas, mimeo.

Lewis, S. (1989): Primary exporting countries, in $\mathbf{H}$. Chenery and T. Srinivasan (eds), Handbook of Development Economics, vol. 2, Amsterdam, Elsevier Science Publishers.

Londero, E. and S. Teitel (1996): Industrialization and the factor content of Latin American exports of manufactures, The Journal of Development Studies, vol. 32, No. 4, London, Frank Cass.

Mackintosh, W. (1953): Innis on Canadian economic development, The Journal of Political Economy, vol, LXI, No. 3, Chicago, IL. The University of Chicago Press.

Meiler, P. (1996): La segunda fase exportadora chilena: Elementos para un debate, Santiago, Chile, CIEPLAN, mimeo.

Nadvi, K. and H. Schmitz (1994): Industrial Clusters in Less Developed Countries: Revlew of Experiences and Research Agenda, IDS Discussion Paper, No. 339, Brighton, Sussex, University of Sussex, Institute of Development Studies (IDS)

North, D. (1955): Location theory and regional economic growth, The Joumal of Political Economy, vol. LXIll, No. 3, Chicago, IL, The University of Chicago Press.

Ojainmaa, K. (1994): International Competitive Advantage of the Finnish Chemical Forest Industry, Helsinki, The Research Institute of the Finnish Economy.

Porter, M. E. (1990): The Competitive Advantage of Nations, New York, The Free Press. 
Reve, T. and L. Mathiesen (1994): European Industrial Competitiveness, SNF report No. 35, Bergen, Foundation for Research in Economics and Business Administration/Norwegian School of Economics and Business Administration, June.

Reve, T. and others (1992): A Competitive Norway, Oslo, Tano.

Ritter, A. (1996): Consequences for Canada of Prospective Cuba-United States Relations: From the "Helms-Burton Bill" to Rapprochement, Working Paper series, No. 15, Ottawa, Carlton University.

Roemer, M. (1979): Resource based industrialization in the developing countries: A survey, Journal of $\mathrm{De}$ velopment Econonics, vol. 6, No. 2, Amsterdam, North-Holland Publishing Company, June.

Rouvinen, P. (1996): Advantage Finland: The Future of Finnish Indistries, Helsinki, The Research Institute of the Finnish Economy/The Finnish National Fund for Reseanch and Development.

Sachs, J. and A. Warner (1995): Natural resource abundance and economic growth, Development Discussion Paper, No. 517A, Cambridge, MA, Harvard Institute for International Development.
Scott, A. (1964): The development of the extractive industries, The Canadian Joumal of Economics and Political Science, No. 28, Toronto, Canadian Political Science Association.

Schmitz, H. (1997): Collective Efficiency and Increasing Returns, IDS Working Paper, No. 50, Brighton, University of Sussex, IDS.

Schmitz, H. and M. B. Musyck (1993): Industrial Districts in Europe: Policy Lessons for Developing Countries?, IDS Discussion Paper, No. 324, Brighton, Sussex, University of Sussex, DS.

Stumpo, G. (1996): Encadenamientos, articulación y procesos de desarrollo industrial, ECLAC, Division of Production, Productivity and Management, mimeo.

Watkins, M. (1963): A staple theory of economic growth, The Canadian Journal of Economics and Political Science, vol. 29, Toronto, Canadian Political Science Association, May.

Yeats, A. (1991): Do Natural Resource-Based Industrialization Strategies Convey Important (Unnecognized) Price Benefits for Commodity-Exporting Developing Countries?, Policy Research and External Affairs working papers, No, 580, Washington, D. C., World Bank. 